\title{
Environmental remediation and its discontents: the contested cleanup of Vieques, Puerto Rico
}

\author{
Katherine T. McCaffrey ${ }^{1}$ \\ Montclair State University, USA
}

\begin{abstract}
Since protest forced the US Navy off Vieques Island, Puerto Rico in 2003, the US military has embarked on one of the largest environmental remediation projects it has ever undertaken. This article explores the way a narrowly conceived, technocratic cleanup process is translated onto an island with a deep history of grassroots mobilization and antagonism towards federal authority. The Restoration Advisory Board (RAB) is a crucible for considering the uneasy dynamics of cleanup. US law enshrines the RAB as the principal venue for "public participation" in the cleanup process. However, the prevailing technocratic framework, constrained by underresourced bureaucratic agencies, clashes with more encompassing concepts of environmental justice. Citizen members of the RAB, nonetheless, approach the committee as a point of access to information about the remediation process, and leverage their participation as a tool for advancing a broader set of environmental justice claims.
\end{abstract}

Key Words: environmental remediation, military, Environmental Protection Agency, US Navy, US Fish and Wildlife Service, environmental justice, citizen participation, Puerto Rico.

\section{Résumé}

Des protestations ont forcé l'US Navy à quitter l'île de Vieques, à Puerto Rico, en 2003. Depuis lors, l'armée américaine a mené l'un de ses plus grands projets d'assainissement de l'environnement. Cet article explore comment un processus de nettoyage technocratique est traduit sur une île avec une histoire profonde de mobilisation de la base et d'antagonisme envers l'autorité fédérale. Le Restoration Advisory Board (RAB) illustre la dynamique difficile du nettoyage. La loi américaine fait de la RAB le principal lieu de «participation du public» au processus de nettoyage. Cependant, le cadre technocratique dominant, contraint par des organismes bureaucratiques sous-financés, se heurte à des concepts plus englobants de justice environnementale. Les citoyens membres du RAB approchent le comité comme un point d'accès à l'information sur le processus d'assainissement. Ils utilisent leur participation comme un outil pour faire avancer un ensemble plus large de revendications de justice environnementale.

Mots clés: assainissement de l'environnement, militaire, Environmental Protection Agency, US Navy, US Fish and Wildlife Service, justice environnementale, participation citoyenne, Puerto Rico.

\section{Resumen}

Desde que protestas forzaron a la marina de Estados Unidos a abandonar Isla de Vieques, Puerto Rico en 2003, las fuerzas armadas estadounidenses emprendieron uno de sus mayores proyectos de descontaminación. Este artículo explora la manera en que un proceso de limpieza, tecnocrático y de estrecha planeación, se traduce a una isla con una larga historia de movilizaciones populares y de antagonismo contra la autoridad federal. La Junta de Consejo para la Restauración (RAB) es la razón para considerar la complicada dinámica en el proceso de limpieza. Las leyes estadounidenses consignan al RAB como la principal instancia para la "participación pública" durante la limpieza. Sin embargo, el marco tecnocrático que prevalece, limitado por agencias burocráticas con bajo presupuesto, se enfrenta con más amplios conceptos de justicia ambiental. Miembros ciudadanos de RAB, no obstante, se acercan al comité como punto de acceso a información relacionada con el

\footnotetext{
${ }^{1}$ Dr. Katherine T. McCaffrey, Associate Professor of Anthropology, Montclair State University, Montclair, NJ 07043, USA. Email: mccaffreyk "at" montclair.edu. The author would like to thank the dedicated civilian and professional members of the Vieques Restoration Advisory Board who took the time to speak with me at length. Additional thanks to the editors of JPE, Casey Walsh and Simon Batterbury for their guidance; two anonymous reviewers and David Havlick for their insightful comments on earlier versions of the manuscript; and Howard Fischer for his editorial help. Special thanks to Bonnie Donohue for her consistent generosity, collegiality, and expert help with the visuals in this article.
} 
proceso de limpieza y aprovechan su participación como una herramienta para avanzar hacia un más amplio conjunto de demandas de justicia ambiental.

Palabras Clave: limpieza ambiental, fuerzas armadas, Environmental Protection Agency, Marina de Estados Unidos, US Fish and Wildlife Service, justicia ambiental, participación ciudadana, Puerto Rico.

\section{Introduction}

Since protest forced the U.S. Navy off Vieques Island, Puerto Rico in 2003, the military has removed more than 95,000 unexploded bombs and expended over US $\$ 215$ million on clean up (US EPA 2017). For over sixty years, Vieques, a Puerto Rican island municipality with 10,000 civilian residents, served as a major training ground and live firing range for the U.S. Navy's Atlantic Fleet. Over time, the intensification of bombing and maneuvers, and growing concerns about their economic, environmental and health effects, sparked grassroots protest. Ten years of steady organizing and a dramatic civil disobedience movement, coupled with substantial national and international support, culminated in the Navy's exit. Now a major cleanup is underway.

By the time environmental remediation is complete, the Navy estimates that the Vieques munitions cleanup will be the largest it has ever undertaken. The cleanup of firing ranges is complex. Over the past thirty years, the Department of Defense (DoD) has transferred millions of acres of former munitions ranges for other purposes. Land contaminated by munitions may have soil, ground water and surface water contamination from leaching munitions residues, which include explosives, heavy metals, chemical warfare agents, and depleted uranium (US EPA 2016). In Vieques, environmental remediation encompasses the unprecedented underwater cleanup of ordnance from thousands of marine acres characterized by landscape features such as coral reefs, dense vegetation, and steep cliffs. The Navy touts the economic impact of cleanup on a local level: it hires local residents to participate on cleanup crews, contracts supplies from local vendors, and houses employees on the island, bringing over US $\$ 41$ million in benefits to Vieques since 2005 (US EPA 2017). On a local level, however, where the cleanup effort is most visible, there is widespread consensus that the Navy has done nothing to address military contamination. In this article I am interested in exploring the contradiction between the cleanup effort to date and the public perception of military intransigence.

Taking a political ecology approach, I consider the unequal relations of power that shape the nature and scope of the environmental remediation. The technocratic process treats cleanup as a relatively value-free endeavor where community participants can comment on the comprehensiveness of a particular cleanup activity, while sidestepping the more encompassing issues of community health, lack of land sovereignty, and competing narratives of risk. Not only does this narrowly conceived technocratic approach to cleanup exclude participants from defining the nature of the process: bureaucratic structures limit meaningful participation. Finally, there is a limited notion of what supervision actually entails, with military subcontractors carrying out work without the physical presence of the EPA on site, and key stakeholders marginalized from oversight in the process. Thus the merger of a highly technocratic process with a highly bureaucratic yet under-resourced approach makes it difficult for key stakeholders to contribute in meaningful ways to cleanup and site restoration, and fails to mobilize broad community participation.

The Restoration Advisory Board (RAB) is a crucible for considering the uneasy dynamics of cleanup. Federal law enshrines the RAB as the principal venue for "public participation" in the cleanup process. The $\mathrm{RAB}$ serves as a forum for the exchange of information and collaboration between citizens, the DoD, the Environmental Protection Agency (EPA), and the state (or in the case of Puerto Rico, the Commonwealth). Citizen volunteers are invited to attend quarterly meetings organized by the DoD where they can receive updates on the environmental remediation process. Pulido, Kohl and Cotton (2015) question the efficacy of achieving environmental justice goals by engaging the state on its own terms. Bureaucratic structures such as the RAB, they argue, circumscribe active citizen participation, and divert energy from other tactics that might be more successful in advancing environmental justice. Careful analysis of the Vieques RAB, however, reveals that residents exhibit a strong degree of caution in engaging with federal authorities: sixty years of adversarial relations with the federal government, including direct action protest, inform healthy skepticism of the clean up 
process. Through situational analysis of several moments of conflict over the cleanup process, I consider the way the prevailing technocratic framework, constrained by under-resourced bureaucratic agencies, clashes with more encompassing concepts of environmental cleanup. Citizen members of the RAB, however, approach the committee as a point of access to information about the remediation process, and leverage their participation as a tool for advancing a broader set of claims.

Research was comprised of the following: first, careful documentary analysis of 15 years of RAB minutes, reports, and presentations, which provided a rich source of primary data on the long-term dynamics of the advisory board. Second, semi-structured interviews with active citizen volunteers of the RAB board, and analysis of citizen volunteer comments in the official record. Third, semi-structured interviews with federal and municipal officials including the EPA and US Fish and Wildlife Service (USFWS) site managers and employees; Navy project managers; municipal officials and analysis of their comments, and those of commonwealth representatives in the official record. Finally, my analysis rested on long-term ethnographic research in Vieques extending back to the early 1990s, and participant observation in Vieques during the summer of 2014.

\section{The politics of environmental remediation}

From 1941-2003, Vieques, a residential Puerto Rican municipality, was also a major U.S. Naval installation in the Caribbean (Figure 1). Its civilian population of 10,000 was wedged between an ammunition storage facility and a live fire zone. Beginning in 1947, amid Cold War fears of nuclear escalation, the Navy semi-annually deployed massive numbers of troops to Vieques for maneuvers, where the island was bombed and strafed from the air, hit with missiles launched from battleships at sea, torpedoed from submarines, and subjected to amphibious landings and extensive ground fire.

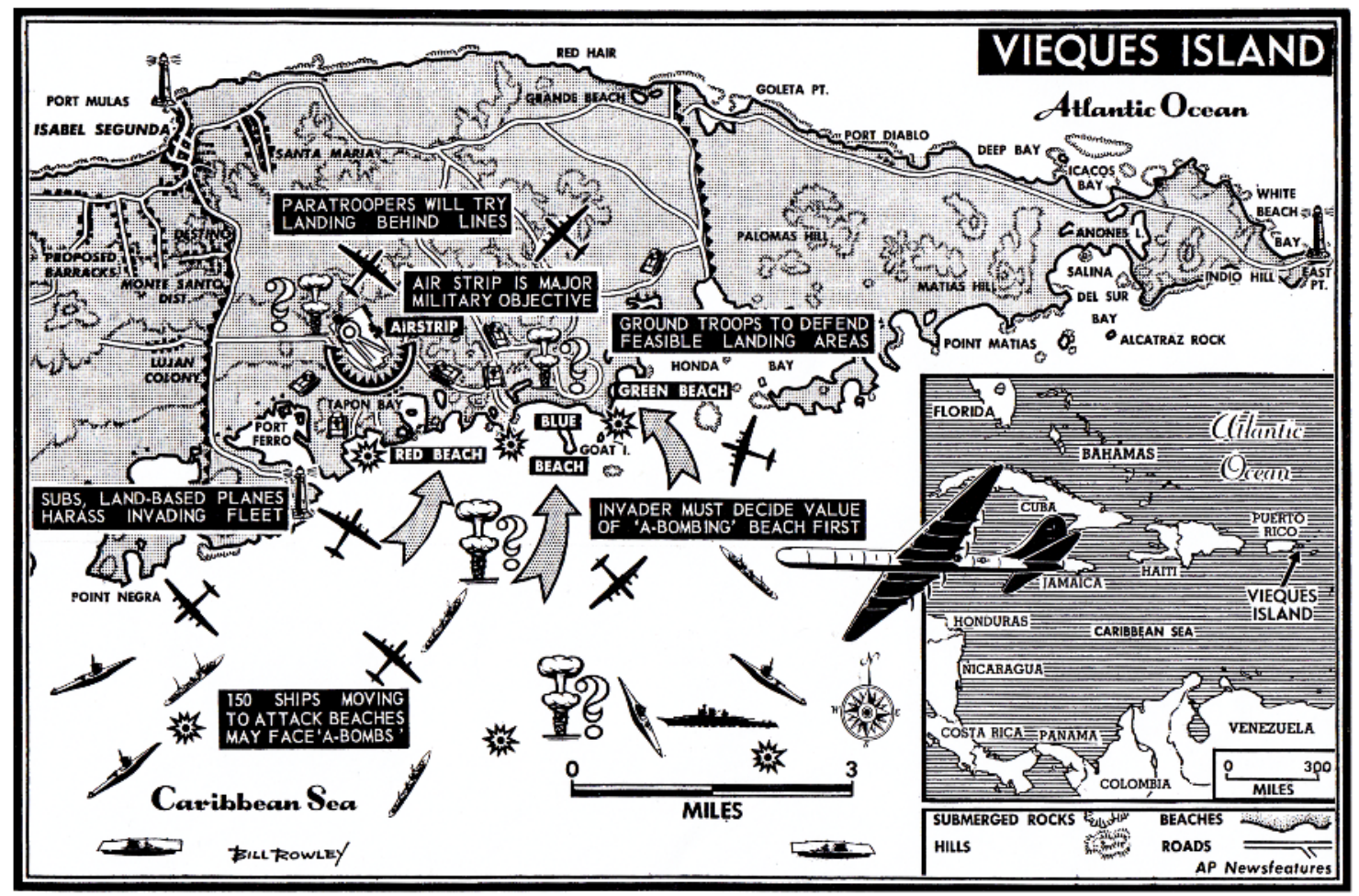

Figure 1: Vieques, 1953, Expeditionary Warfare Training Group, Atlantic, Box 7: LANT PHIBEX II-53, Marine Corps Archives, Quantico, VA. Courtesy of Bonnie Donohue. 
Tension between these conflicting purposes-theater of war and civilian community - sparked protest over the years of military occupation, culminating in a powerful grassroots movement that drove the Navy from Vieques in 2003. According to the Navy, in 1998, the last year before protest interrupted maneuvers, Vieques was bombed an average of 180 days per year. ${ }^{2}$ The navy dropped 23,000 bombs on the island, the majority of which contained live explosives. Overall, the island is estimated to have received 80 million pounds (36 million $\mathrm{kg}$ ) of ordnance in the second half of the $20^{\text {th }}$ century. The point of the most intense destruction is the live impact range, which constitutes about 980 acres (367 ha) on the island's eastern tip. Yet all 14,000 acres (5,666 ha) and 11,500 underwater acres (4,654 ha) adjacent to range and operational areas on East and West Vieques have been affected by military practices including naval gunfire training, aerial bombing, amphibious landing, and toxic waste disposal. In the military base conversion process, the cleanup of firing ranges has proved one of the most dangerous, expensive, and challenging tasks (Sorensen 1998). Although land in the west (Figure 2) has not suffered the severe ecological destruction of constant bombing, the Navy used multiple sites there as dumping grounds for a variety of hazardous materials. Nearly 2 million pounds $(907,200 \mathrm{~kg})$ of military and industrial waste —oils, solvents, lubricants, lead paint, acid and other refuse—-were disposed at different sites in mangrove swamps and sensitive wetland areas.

In response to massive and sustained protest, the Navy terminated its operations in Vieques in two stages. First, it withdrew from the western portion of the island, a total of 8,100 acres (3,278 ha), where it had maintained a small operating base and ammunition facility. Congress instructed the Navy to transfer 3,100 acres (1,255 ha) to the Department of Interior for management as a National Wildlife Refuge. Some 5,000 acres (2,023 ha) were reverted to the Municipality of Vieques and the Puerto Rico Conservation Trust for conservation purposes. Land there is shaped by the presence of 108 blast-proof bunkers that significantly constrain the shape of development on that terrain, but are not part of the environmental remediation plan (McCaffrey 2015).

When this concession failed to quell protest, President George W. Bush issued an executive order in 2001 to end all naval operations on the island. The 2001 National Defense Authorization Act, drafted by Congress, established the disposition of eastern property that fundamentally shapes the current controversy. Congress instructed the Navy to transfer its 14,700 acre (5,949 ha) eastern landholdings, the site of its Eastern Maneuver Area and Atlantic Fleet Weapons Training Facility, to the Department of Interior, which would administer most of those properties as wildlife refuges under the National Wildlife Refuge Act of 1966. The live impact zone, the 900 acre (364 ha) bombing range within the eastern territory, was treated differently. Congress instructed the Department of Interior to administer that area as a "wilderness area" under the Wilderness Act and "deny public access to the area." ${ }^{3}$ David Havlick (personal communication), notes that it is extremely unusual and incongruous to designate former military land as a wilderness preserve ${ }^{4}$, and the additional provision denying public access is extraordinary. There is very little about the bombing range that qualifies it as a wilderness zone, but denying public access conveniently limits the Navy's cleanup requirements (McCaffrey 2009).

\footnotetext{
${ }^{2}$ In a press briefing, Secretary of the Navy Richard Danzig indicated that the 180 days the Navy fired on average in 1998 represented a 50\% drop in firing from 1983, when protest pushed the Navy to sign a good neighbor agreement, the Memorandum of Understanding with the Government of Puerto Rico.

U.S. Department of the Navy Press Briefing. The National Security Need for Vieques: A Study Prepared for the Secretary of the Navy. Thursday, July 15, 1999.The Pentagon, Washington, DC. Secretary of the Navy Richard Danzig Commander, U.S. Second Fleet Vice Admiral William J. Fallon Commander, U.S. Marine Corps Forces Atlantic Lieutenant General Peter Pace.

${ }^{3}$ Closure of Vieques Naval Training Range and Disposal of Closed Range. Sec 1504. National Defense Authorization Act 2001.

${ }^{4}$ The Wilderness Act of 1964 (16 U.S. Code § 1131) defines wilderness as "an area of undeveloped Federal land retaining its primeval character and influence... which is protected and managed so as to preserve its natural conditions and which (1) generally appears to have been affected primarily by the forces of nature, with the imprint of man's work substantially unnoticeable."
} 


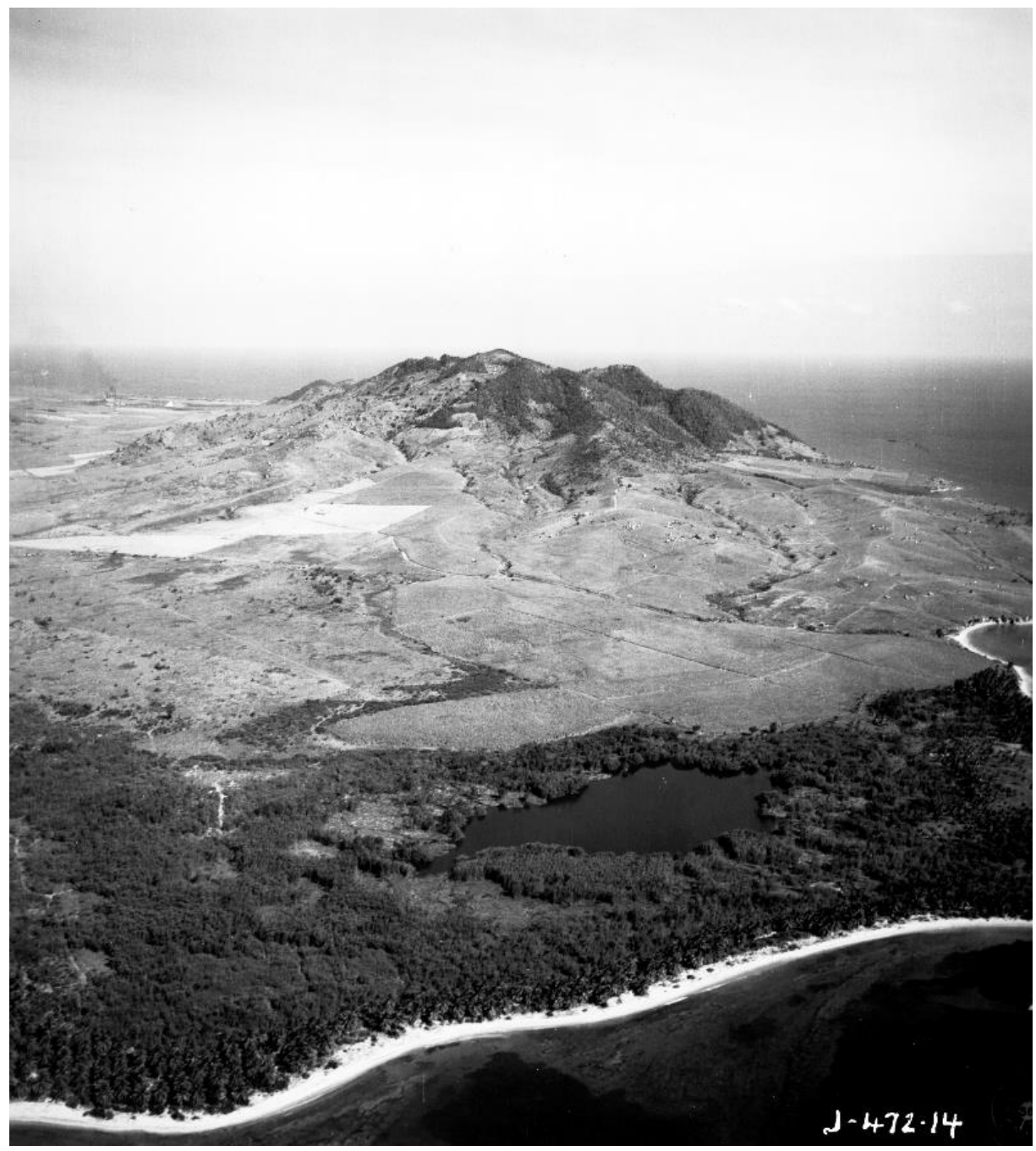

Figure 2: U.S. Navy aerial survey "West End of Vieques Island," March 18, 1941. Boca Quebrada Lagoon is featured in the foreground inside the coconut grove. NACP, 71-CA-412D - Puerto Rico - Vieques Island. Courtesy of Bonnie Donohue.

The degree of cleanup is legally defined by the degree of public safety hazard. Unexploded ordnance (UXO) is an urgent threat to public safety, but only if the public encounters it. Land use policy, masked in the phraseology of the risk assessment paradigm, is therefore inextricably intertwined with the environmental remediation process. This federal report clearly summarizes the situation:

The scope of the cleanup will depend on public safety hazards posed by the presence of munitions and whether a pathway of human exposure to munitions-related contamination exists. The Live Impact Area of the former bombing range that is to be administered as a Wilderness Area is likely the most contaminated portion of the island. As the National Defense Authorization Act for FY2002 prohibits public access on this land, a pathway of exposure through human contact with soil or surface water presumably would not be present if this prohibition is enforced. Consequently, cleanup may be less extensive than if the land were designated for uses that would 
involve human presence. However, if the cleanup investigation were to reveal that contamination has migrated off-range and presented a pathway of exposure, the Navy could be subject to more stringent cleanup actions. Similarly, the Department of the Interior could limit public access to lands outside of the Live Impact Area that are to be administered as a National Wildlife Refuge, if munitions hazards are present. If access to these lands were restricted, the Navy could be subject to less stringent cleanup requirements there as well, unless contamination were to migrate to areas where people are present. (Bearden 2005: 13)

It is not uncommon for former military bases to be converted to nature preserves. Havlick notes a startling shift in U.S. land use since the late 1980s as over two dozen military sites have been transformed from national defense to wildlife conservation (2018). Indeed, Havlick notes that the post Cold War trend of militaryto-wildlife transitions, "represent(s) an important trend in conservation and ecological restoration on hundreds of millions of acres from central Europe to East Asia, throughout the United States and on islands and marine reserves across the Pacific Ocean." Vieques is unusual, though, because the island hosted a large base and a municipality with a resident population of 10,000 U.S. citizens. Just as the dual military/residential use of the island created significant conflict over the years of weapons training, so this legacy creates conflict over the cleanup agenda. Residents are not content to turn the former base land into an undeveloped nature preserve: rather, most want some sort of socioeconomic development, including an expanded ferry service, medical facilities and most importantly, job opportunities.

The Vieques remediation project reveals the way that science and technocratic decision-making have become an increasingly dominant force in shaping social policy and regulation in the United States. The insatiable search for better science, "clearer evidence" has become a significant and powerful tool used to support dominant political and socioeconomic systems. As Ulrich Beck notes, through

...this "scientization" of decision making, industry [or, in this case, the Navy] exerts considerable control over debates regarding the costs, benefits, and potential risks of new technologies and industrial production by deploying scientific experts who work to ensure that battles over policy making remain scientific, "objective" and effectively separated from the social milieu in which they unfold. (Beck 1992)

The end result of this process is that questions are posed to science that are virtually impossible to answer scientifically due to data uncertainties or the infeasibility of carrying out a study. Second, the process inappropriately frames political and moral questions in scientific terms, thus limiting public participation in decision making and ensuring that it become the purview of "experts" (Weinberg 1972). Science becomes the idiom through which political controversies are waged over the effects of environmental exposure (Shostak 2013: 27-28). The Navy's usurpation of land and disregard for the safety and wellbeing of the 10,000 American citizens who lived on the island is an expression of Puerto Rico's lack of sovereignty and political power over its destiny. This core conflict has never been addressed through the political process, despite the Obama administration's recognition that "there is much the Federal government can do to improve the quality of life for people in Vieques." ${ }^{5}$ Efforts to hold the Navy legally responsible for harm in Federal courts were stymied by sovereign immunity legal doctrine that holds states immune from civil suit or criminal prosecution. ${ }^{6}$ The sole federal acknowledgement of its destructive past is shifted to underfunded regulatory agencies with limited resources to investigate the complexities of science. ${ }^{7}$ Not surprisingly, their investigations do not yield answers.

\footnotetext{
${ }^{5}$ Report by the President's Task Force on Puerto Rico's Status. Washington, D.C. March 11, 2011. (p.12).

${ }^{6}$ A district court and then the U.S. Court of Appeals for the First Circuit dismissed Sanchez et al. v. United States, a case filed against the U.S. alleging tort injuries due to the Navy's negligence in emitting pollutants during military exercises. The Supreme Court declined to hear the case in 2013.

${ }^{7}$ Perhaps the most egregious example of this is the Agency for Toxic Substances and Disease Registry (ATSDR), an agency that was created to function as the public health wing of the EPA, but instead has emerged as a primary apologist for polluters. A three year investigation by watchdog groups the Environmental Health Network and the National Toxics
} 


\section{From environmental justice to technocracy}

In 2005 Puerto Rico Governor Sila Calderón leveraged what little political power the Puerto Rican government holds on a federal level to force the hand of the Navy to clean up its mess. Utilizing a "silver bullet" provision in federal law, Calderón designated Vieques, together with the former U.S. military range on the neighboring Culebra Island, as federal 'Superfund' sites, a status generally reserved for the U.S.'s most hazardous toxic sites. Utilizing this executive prerogative, Calderón bypassed a lengthy regulatory process and placed Vieques and Culebra on this National Priority List (NPL), which ensured that the Navy would address the environmental disaster it left in its wake. ${ }^{8}$

Vieques' Superfund status presents a paradox. Its designation situates Vieques among the top national priorities for environmental remediation, and clearly privileges Vieques in comparison to foreign bases such as former firing ranges in Panama (Empire Range, Balboa West Range, Bailamonos, Rio Hato, Fort Sherman, Iguana Island) and Subic Bay and Clark Air Force Base in the Philippines, where the U.S. military has avoided responsibility for toxic waste and munitions at decommissioned bases (Lindsay-Poland 2003). However, it raises a public expectation of environmental cleanup that is not met by a notably circumscribed, risk analysis framework. Beneath this framework, the land use designation, a political gesture, limits the environmental site work.

Under federal law the polluter is required to fund and carry out environmental remediation, which is supervised by the EPA. Placing a site on the NPL, however, does not in and of itself guarantee a specific degree of cleanup or particular amount of funding. Cleanup is determined by the threat to human health, safety, and the environment as interpreted by the risk assessment framework. Funding is not automatic. Because the polluter in this case was part of the U.S. government, rather than private industry, Congress allocates funds for cleanup on an annual basis. Vieques, however, which has been a hot-button political issue for the past 10 years, has received significant funding for the cleanup and attention to the pace of remediation. All the money spent and the ordnance removed, however, has not translated into good relations with the community at large. "The cleanup process is a joke", one resident scowled. "The Navy hasn't done anything."

Part of the disenchantment stems from power relations governing the cleanup process. Although the EPA formally oversees the Vieques cleanup, it functions, as Devra Davis notes, "chiefly [as] an information processing agency. .... It neither conducts nor funds basic research on toxic chemicals. Instead, it reviews reports provided to it by the very companies it is supposed to regulate" (2004: 197-198). The EPA site director in Vieques, Daniel Rivera, confirmed this power dynamic:

We're not doing the work. We're just doing the oversight. The Navy generates the data, performs the risk assessment. And we evaluate. We have our own risk assessors who look into the equation. We do the oversight of the cleanup to make sure that it is compliant with all applicable laws and regulation and that it's protective to human health and the environment. The studies are done by the Navy or a contractor, whomever they choose.

\footnotetext{
Campaign Fund culminated in a 1992 report: Inclusive by design: waste, fraud, and abuse in federal environmental health research that showed that the ATSDR was unable to find a connection between pollution and illness in $98 \%$ of its cases. The agency's inability to find connections between pollution and public health, as well as its failure to assess the health hazards of formaldehyde exposures by displaced survivors of Hurricanes Katrina and Rita in FEMA trailers, spurred contentious Congressional hearings in 2008 and 2009. Congress and its investigative arm, the Government Accountability Office (GAO) undertook an inquiry into ATSDR "because of claims that they have consistently used unsound science and incomplete data to make public health decisions." (CEN-Online) June 7, 2010. Puerto Rican scientists pointed to the ATSDR's pattern of using erroneous data in multiple analyses: for example, in its soil pathway evaluation (ATSDR 2001) which concluded that there were no health risks to the population associated with soil contamination. The ATSDR asserted multiple times that $82 \%$ of naval ammunition used on the Vieques range was non-explosive, when in fact, according to the Navy, a majority (60\%) was explosive. When challenged, the agency did not correct its error, leading to charges that it was deliberately concealing evidence (Committee on Environmental and Health of the Technical and Professional Support Group for the Sustainable Development of Vieques 2001).

${ }^{8}$ It should be noted that until Calderón took this action, the military had not cleaned up any of the former firing range of Culebra that it vacated 30 years earlier.
} 
Thus scientific knowledge, presumed to exist outside institutional, cultural and historical contexts, is clearly embedded in existing and unequal relations of power.

Adding an additional, politically incendiary element to the environmental remediation process, the actual environmental site work is supervised and controlled by the polluter itself: the U.S. Navy. Given the legacy of distrust, this dynamic is a breeding ground for conflict. As Julie Smith (pseudonym), one of the RAB members commented: "The Navy should pay for the clean up—but conduct it?" When, for example, the Navy detonates ordnance, it will declare land off-limits not only to the public, but to the federal agencies one might assume would wield more power than the polluter: the EPA, the environmental supervisor, and Fish and Wildlife, the landlord. As I will discuss, several flash points in the cleanup process stemmed from this power dynamic in which the public regarded the polluter as acting without accountability.

\section{Undermining democratic participation}

Within the Superfund process, community participation is channeled and institutionalized into a Restoration Advisory Board (RAB). The concept of a RAB emerged in the early 1990s in the context of Clintonera (1993-2000) efforts to incorporate equity considerations into the structure and activities of federal agencies. ${ }^{9}$ This was a particularly urgent matter in the early 1990s: in 1995, the U.S. government estimated that there were 61,155 contaminated federal sites across the country, most stemming from former use by the Department of Energy and Department of Defense. A burgeoning environmental justice movement challenged government leadership. With cleanup costs estimated at between US\$230 and US\$390 billion over the next 75 years, both the EPA and DoD recognized that they needed to improve their cleanup process (US EPA 1996). The RAB was created ostensibly as a vehicle for engaging a diverse public in discussion and decision-making.

Early recommendations to the EPA emphasized creating an "open, public consultative process" as the best path towards improving "tenuous and fragile" relationships between communities and federal agencies (US EPA 1996: ix). As Daley and Reames note, public participation in environmental decision making provides an opportunity to increase equity, reduce conflict, and improve overall outcomes. Conversely, its failure exacerbates tensions and breeds mistrust (2015: 145-146). The newly constituted RAB did permit public access to agencies' decisions and allowed citizens to submit recommendations (Holifield 2007). Ultimately, though, the EPA ignored key advice in the way it integrated public input. Citizen participation was conceived mainly in terms of improving public relations rather than improving the remediation process. Critics of Clinton administration reforms note that the overall approach to environmental justice emphasized empowerment over equity: rather than redistributing environmental risk more equitably, reforms revolved around efforts to "empower" and "build trust" in communities suffering from environmental injustice by encouraging participation (Holifield 2007).

In Vieques, the limitations of the RAB are apparent. Meaningful public participation requires resources and a commitment to a participatory process, both of which are lacking. For example, there are insufficient resources devoted to Spanish interpretation at meetings, translation of documents, and public dissemination of materials. The decision-making structure itself is top-down and expert-driven. Perhaps the gravest flaw in the remediation process, however, is its reliance on a risk assessment that is designed to anticipate future harms and thus sidesteps these crucial legal, moral and ethical questions about the federal government's responsibility for damage incurred over 60 years of military occupation. Masquerading as "objective" science, all lead federal agencies - from the DoD, to the EPA, to the ATSDR—operate under this framework which itself is shaped by certain value-laden assumptions about what constitutes danger, how it is measured, and how it is resolved.

\footnotetext{
9 The EPA chartered an advisory committee, the Federal Facilities Environmental Restoration Dialogue Committee (FFERDC), that convened an impressive coalition of diverse parties spanning military and federal agencies to tribal governments, labor and environmental justice organizations to discuss improving cleanups at federal facilities. By 1999, however, the EPA already departed from core principles, distilling the advice of the advisory board into a watered down version of four key ideas: there should be sharing of information, environmental justice (achieved through incorporating diverse members in environmental justice "programs"), establishing advisory boards, and incongruously, "understanding the federal budget process." This last point was never mentioned in the original document. See Federal Facilities Environmental Restoration Dialogue Committee. 1999. A blueprint for creative solutions.
} 
Presciently, outside consultants warned the EPA against the adoption of a risk analysis framework in environmental remediation, identifying it as an ideological obstacle to cleanup:

Risk assessments... often create an illusion of scientific knowledge and certainty. The data used to produce risk assessments are often limited and, in any case, must be subjected to interpretation. Moreover, the assumptions used are often the subject of intense scientific debate. The manner in which risk assessments are developed, communicated and utilized often does not consider how many individuals do not have, or are not provide with, information about how the assumptions are developed, the quality of the data used, and how the data and assumptions are used to produce the estimate of risk. (US EPA 1996: 22)

Since the early 1990s, Vieques activists have mobilized concern about the public health impact of military training exercises, and thus there is widespread public understanding that "cleaning up" the environment involves addressing the human dimensions of military contamination. For nearly 30 years, controversy has swirled around the cancer rates on the island, and its relationship to 60 years of intensive military training. In 1999, the Puerto Rican Health Department's Cancer Registry published an analysis of cancer trends for Vieques and the main Island of Puerto Rico between 1960-1994. The analysis (Zavala-Segarra 1999) revealed that Vieques exhibited cancer rates lower than those of the main Island until 1979-a year that coincided with the intensification of bombing - when cancer rates increased at alarming levels. In 2009, the Puerto Rican Department of Health demonstrated that the prevalence of cancer in Vieques was 27 percent higher than in the rest of Puerto Rico (Figueroa et al. 2009). As part of a lawsuit brought against the Navy by Arthur Eaves, hair samples were collected from the population, revealing startling levels of arsenic, lead, and heavy metals in people's bodies. Residents want to know why they are sick, what the relationship is between military practices and illness, and how the cleanup process will help them recover their health.

The risk assessment process that governs the Vieques cleanup, however, does not approach the consistent public demands for decontaminating the island. Rather, risk assessment attempts to quantify danger through a reductionist formula that regards risk as a balance between the magnitude of potential loss versus the likelihood that such a loss will occur. Corburn succinctly describes the process (2005: 25): first, an investigator will seek to identify specific pollutants such as toxins in the air. Once identified, the toxins are assessed for their toxicity, or their potential harm on humans generally. Determinations of human-health impacts in a specific place generally include assumptions about the routes of exposure (for example, inhalation) how much pollution certain groups are inhaling (for example, babies versus fire fighters) and how long certain groups are exposed. The toxicity information and exposure assumptions are combined to estimate the human health risk from each individual pollutant. The risk frame tends to privilege formal, quantitative data and the select group of professionals who can produce such data (Corburn 2005, Jasanoff 1986). Experts are chosen based on their technical competence, on their ability to construct "objective science", that is presumably politically independent and neutral. (Corburn 2005, Frickel and Moore 2006). In Vieques, this translates into a cleanup process dominated by English-speaking engineers who have an affinity for delivering mind-numbing charts and maps via PowerPoint presentations (Figures 3, 4).

Significantly, the risk frame is organized to predict future harm. Based on this understanding, the Navy prioritizes the removal of unexploded ordnance (UXO) as the gravest threat to human health. Sites with high concentrations of toxic waste, such as former disposal sites, also merit attention. Residents, however, are interested in science as a mechanism to validate the harm that they have suffered due to past military exercises. Yet the risk analysis is not designed to investigate the cumulative effects of military toxins over time. It reveals nothing about early life exposure to toxins, or the role of agents that do not persist in the environment, such as many plastics, fuels and volatile compounds (Davis 2004). Also beyond the purview of the risk frame are the interactions of various substances that might be harmless alone, but lethal in combination. Thus the risk frame clashes with residents' desire to understand the impact of past military practices on the current health of islanders, and ultimately their desire for justice. 


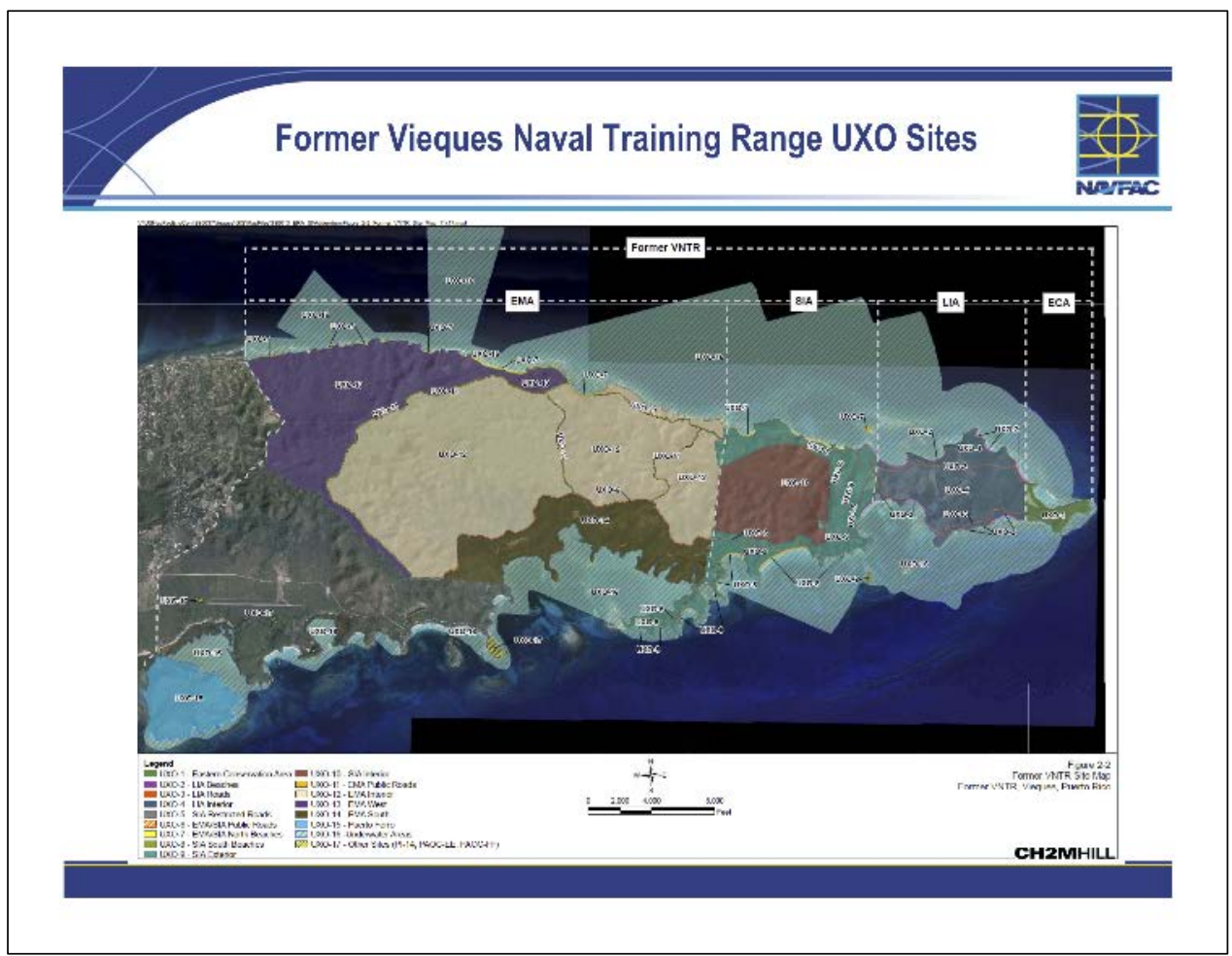

Figure 3: Excerpt from slide presentation, "Engineering evaluation and cost analysis for east Vieques, site 13 (UXO-13)." RAB meeting November 15, 2011.

One important dimension of the risk assessment process that has dramatic implications for the Vieques cleanup process is its emphasis on the pathways of exposure. Risk is quantified by the likelihood of exposure: therefore, places where people will come into contact with ordnance or toxic waste receive the highest priority for cleanup. Yet UXO removal is predicated on a policy vision of land use that limits human access to former military controlled areas. Land policy, determined unilaterally by Congress, underscores the way Puerto Rico's lack of sovereignty shapes the core dynamics of ongoing controversy. By transferring land to the US Fish and Wildlife Service, Congress turned the agency into an unwitting landlord, charged with protecting wildlife and restricting access to land to which residents feel entitled. When I asked local EPA head Daniel Rivera what power the agency wielded to force the Navy to cleanup he explained the dynamics succinctly:

The law only gives us oversight capacity to the point of land use designation. Whatever the land use designation, that determines our capacity to protect human health and the environment. For example, if that land had become residential, the story would have been different. But a nature reserve, or a wildlife refuge, Fish and Wildlife agrees that they won't allow anyone to traverse there. So there is no access for you to come into contact with the munitions. There is no human health risk. 


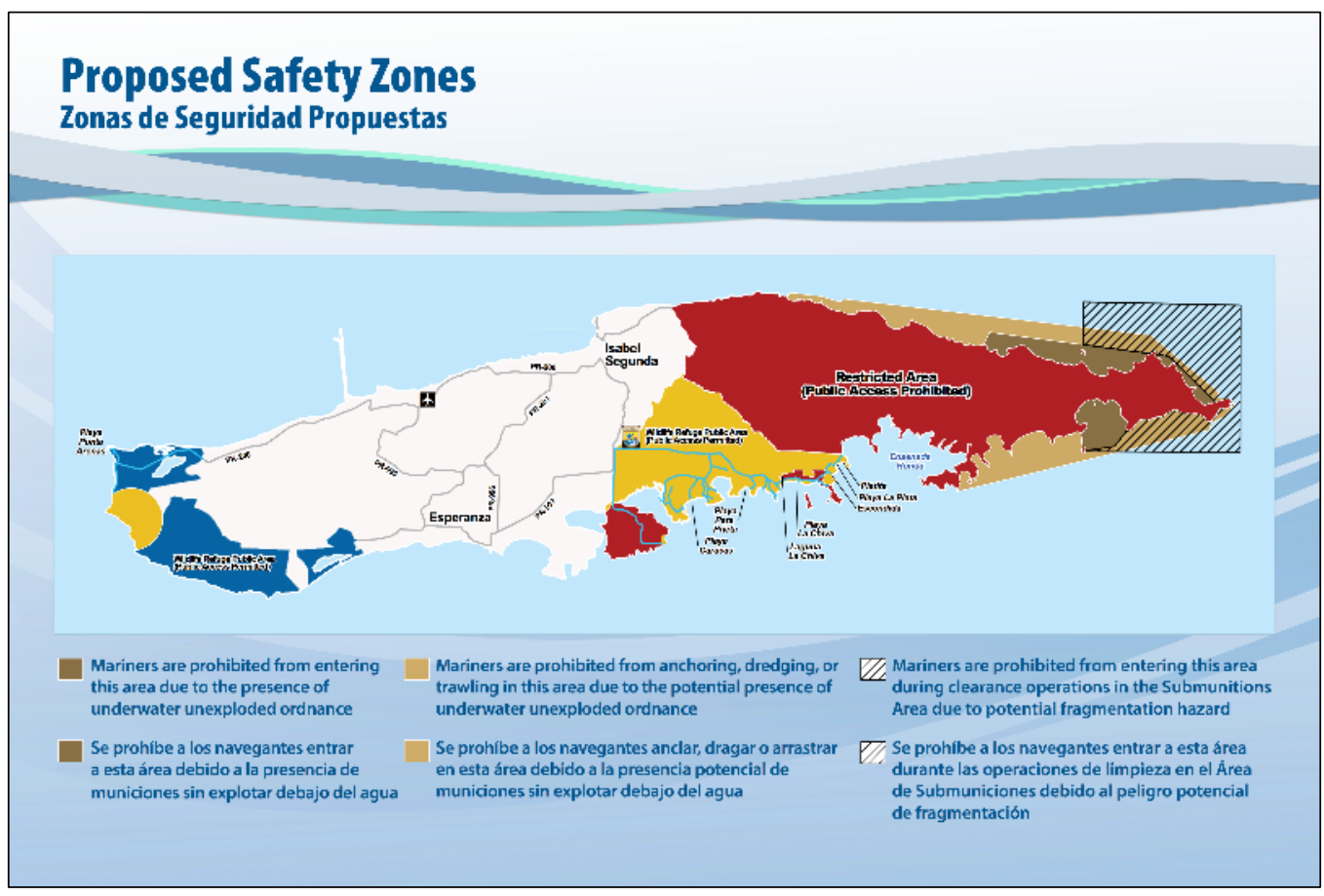

Figure 4: Poster recommending restricted access to most Eastern land. RAB, August 2017.

\section{Technocracy and its critics: the Vieques RAB}

The Restoration "Advisory Board" is a civilian group with no legal authority to direct the cleanup process. Rather, the committee serves as a receptacle for dozens of highly technical reports produced in English, on which members are invited to comment. Their comments, however, are non-binding. The expectation is that the process will allow community members to understand the rationale of the cleanup process, which is designed by technical experts, not to change it or challenge its assumptions. Despite these profound limitations, the Vieques RAB does provide an entry point for citizen activism and moments of opportunity to influence the nature and goals of cleanup. ${ }^{10}$

The RAB is not a representative body, a fact that member Jorge Fernández Porto is quick to recognize:

I would like more people to be involved in the process. I am not representing anyone. I am representing myself. It is an important process-more people should go. You don't have to be an expert. Your presence is important-it puts pressure on the cleanup. I hear people complain that the meetings are too boring, too technical, that nothing comes out of them. That's not true. When someone comes and doesn't understand something, they stop and explain. It's not so difficult to understand. The positive side is to put some pressure on them.

Fernández is an environmental scientist and the technical advisor to the Puerto Rican Independence Party (PIP) who resides on the main island of Puerto Rico. Arrested in 2000 alongside PIP president Rubén Berríos, he is clearly not a "typical" Viequense, although pursuing environmental justice for the island is a long time personal

\footnotetext{
${ }^{10}$ Prior to its status as a Superfund site, the Navy had established a Technical Review Committee to inform citizens about the status of cleanup on western Vieques that was initiated in advance of the federal directive. A similar forum, however, had not yet been established for the eastern areas being investigated under RCRA. With the Superfund designation, and at the request of the community, the Navy converted the Technical Review Committee into a Restoration Advisory Board (RAB) in FY2004. As Vieques is now listed as a single site, residents are able to receive information about the cleanup of both the western and eastern portions of the island through the RAB as one centralized forum.
} 
and political goal. Like other members of the board, Fernández is fluent in English, the primary language of the presentations and reports.

In the RAB meetings, English-speaking engineers present PowerPoint slides that quantify the number of hazardous sites under investigation, and the pieces of ordnance collected. They present dozens of maps that depict Vieques as a series of zones designated by acronyms. Slides are simultaneously simplistic and inaccessible. Value judgments creep into language that is presented as scientific fact. For example, one meeting presented a "study" of depleted uranium munitions in 7 facile slides ${ }^{11}$ (Figure 5).

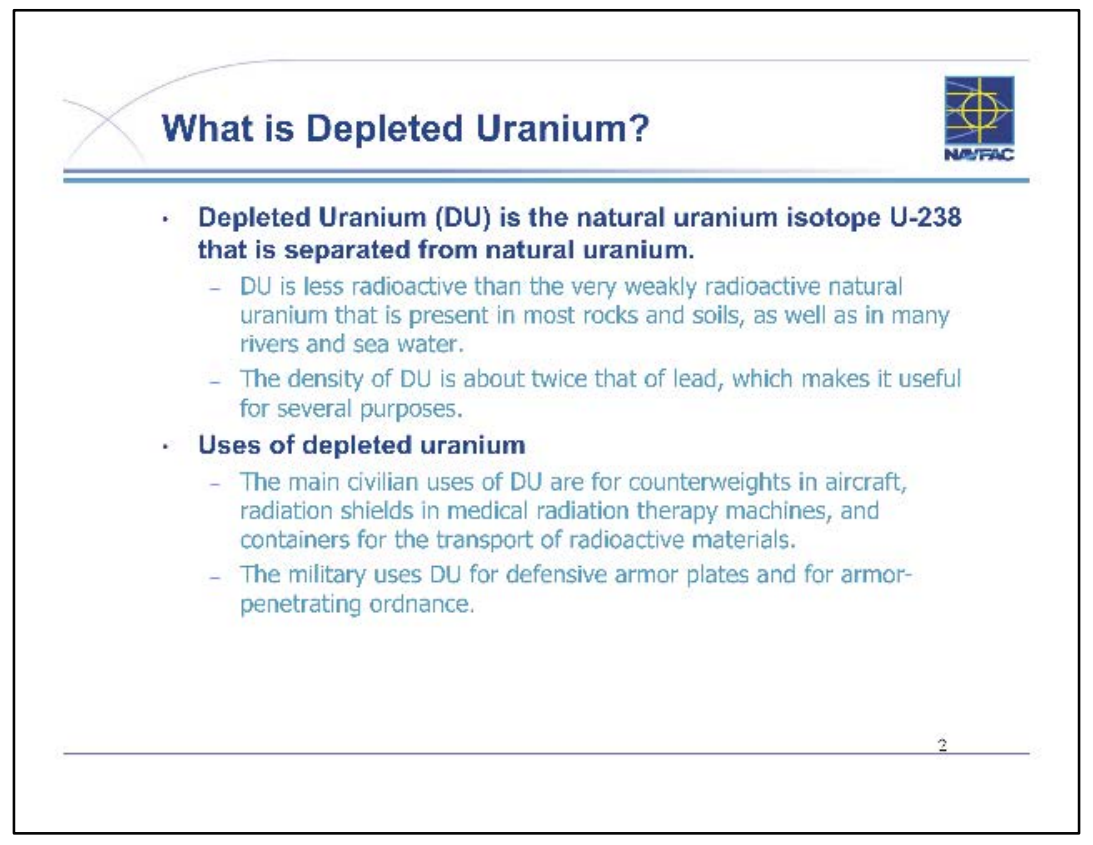

Figure 5: Excerpt from RAB community presentation about source of, and uses for, Depleted Uranium.

While depicting depleted uranium as natural, harmless and useful, this presentation conveniently overlooked several important aspects of DU that animate controversy in Vieques. First, depleted uranium is a byproduct of the uranium enrichment process, thus lending credence to the idea that DU munitions risk exposing people to nuclear waste. DU, according to the EPA, "is both a toxic chemical and radiation health hazard when inside the body." 12 "It is unlikely that the average person would come into contact with DU", notes the EPA, but Vieques is an exception to the average. The second dimension informing public reaction to DU munitions is 60 years of military secrecy and impunity. In 1999, through the Freedom of Information Act, activists uncovered an apparent Navy mishap in which it fired DU munitions on the Vieques range, in violation of federal law and Navy regulations that restrict their use to combat zones. The Navy admitted to firing 263 shells, but ultimately only recovered 57 rounds. ${ }^{13}$ Although the Navy notified the U.S. Nuclear Regulatory Commission of the event, it neglected to notify the Puerto Rican government, thus fueling charges of cover-up and a lack of transparency. More recently, revelations of top secret chemical and biological warfare tests

\footnotetext{
${ }^{11}$ Vieques Restoration Advisory Board Meeting, Summary of depleted uranium studies. August 2008.

12 http://www3.epa.gov/radtown/depleted-uranium.html

13 https://www.nrc.gov/docs/ML0036/ML003677595.pdf
} 
conducted on Navy ships from the 1960s, including ships stationed in Vieques, raise anxiety about the nature of military practices, and contaminants unleashed on the island. Detailed information remains classified. ${ }^{14}$

This history shapes the public response to the fresh-faced North American contractors from Virginia and their PowerPoint presentations. Many residents are dismissive, even disdainful of the RAB process. "In the beginning," remembered Hector Oliveri, an activist and a periodic Municipal representative to the RAB,

When the RAB started, the meeting room was full. People were motivated. Many people in Vieques were interested. But then we realized that the RAB was not designed for the community's interests. The Navy told us what they were doing, but they didn't accept us as part of the process. This was not the kind of cleanup that we wanted. People proposed solutions, but they didn't listen. People stopped attending the meetings.

In Oliveri's estimation, the RAB "doesn't do its job. They set it up because it is legally mandated. The RAB is set up to inform the community. We want to participate."

Even current members of the committee express ambivalence. Stacey Notine, who has been involved in different degrees with the cleanup process since 1996, describes herself as the "rabble of the RAB." "The cleanup process is a joke. We've gotten nowhere." Notine's primary concern is the cancer rate on the island, which she attributes to long term, persistent airborne contamination by military explosives and chemicals. Her top goal, and indeed that of most island residents, is the identification and removal of military-generated carcinogens from the former range. She felt that given the technological sophistication of the U.S., the Navy could easily determine what kind of contaminants were on the bombing range if there were the political will. She is convinced that there are widespread DU munitions on the site, and that one of the disposal sites on the eastern base was used for the burning of Agent Orange. She believes that the Sahara dust that blankets Vieques in the summer may well be full of DU dust (see below).

Community participation in the quarterly RAB meetings fluctuates. Some meetings are attended dutifully by long term members who struggle to keep up with a thick pile of regulatory documents, and who are periodically criticized by neighbors for not doing enough to inform the public. Occasionally, meetings will be occupied by irate members of the public, dissatisfied with some aspect of the cleanup process. The distrust of the Navy and the U.S. government fuels one of the earliest and most enduring conflicts of the cleanup process: the open detonation of UXO. Through the negotiations surrounding open detonation, however, one sees the way that the RAB in Vieques, despite its limitations, does intervene to shape the cleanup process, and provide an opening for activists to shape a highly technocratic process.

\section{The open detonation controversy}

According to the EPA, the most common, safe and cost-effective way of removing UXO is open detonation. Depending upon the size and volatility of the ordnance, it might be blasted on site, or relocated to a nearby location and detonated with other ordnance in a consolidated blast. In general, movement of UXO is not considered safe, and the practice of open detonation minimizes the hazards posed to site workers while demanding the fewest federal resources.

Open detonation, however, has proven to be the most controversial aspect of the cleanup process. Nationwide, in the past decade, veterans and community activists have raised concerns about the military's routine open burning of munitions, chemical weapons and toxic waste at home and overseas. As a result of grassroots mobilization, the 2017 National Defense Authorization bill required the Army to investigate alternatives to open burning the conventional munitions stockpile. ${ }^{15}$ In Vieques, the debate is animated

\footnotetext{
${ }^{14}$ See U.S. Department of Veteran Affairs. Public Health. Military exposures. Project 112/Project SHAD.

P. Kime No difference in death rates for veterans of secret Navy chem-bio tests. Military Times. January 26, 2016 and T. Padgett. Toxic Chemicals at Vieques. Is U.S. accountable? Time. September 16, 2009.

${ }^{15}$ Media attention to the topic includes J. Hickman. 2016. The burn pits: the poisoning of America's soldiers. New York: Hot Books; D. Ross. Toxic and deadly, the human and environmental toll of open burning. Truthout. July 19, 2016. For
} 
additionally by several local concerns. First, open burning reveals conflicting definitions of cleanup: the Navy interprets its responsibility for cleanup as primarily an ordnance-removal project, while activists demand decontamination. The notion that the Navy would approach environmental remediation by releasing more toxins into the air, water, and soil, is a provocation to citizens concerned about public health. Second, Vieques' social movement explicitly mobilized concerns about military contamination throughout the nineties in its efforts to remove the Navy. Activists linked a rise of cancer to the intensification of bombing on the island, and proposed that airborne contamination was sickening residents. The Navy's decision in 1993 to install a massive radar range (ROTHR) intensified concerns about invisible contamination and strengthened the anti-Navy movement (McCaffrey 2002). Health and military contamination have long been crucial pillars of the anti-Navy movement, and now found new expression in the open detonation controversy. Residents who had struggled to stop the bombing exercises that they believed were sickening them feel that the cleanup process is essentially a continuity of past practices that contaminate them.

Third, and finally, life in the Caribbean is shaped by the trade winds that steer the course of hurricanes as well as seasonal plumes of dust particles that travel thousands of miles from the Africa-"Sahara dust." Regional scientists are concerned that Sahara dust may contribute to asthma and respiratory disease, and Puerto Rico periodically issues health alerts due to the concentration of airborne particulates. It is, therefore, common sense that airborne particulates travel long distances and threaten public health. ${ }^{16}$ The Navy's insistence that its own plumes of dust-from bombs detonated several miles from residential neighborhoods-are somehow immune from these patterns clashes with common sense. No matter how many fact sheets the military releases, residents assume that the Navy's inability to detect airborne traces of explosive chemicals, metals and other particulates is proof of its incompetence or cover-up.

With the internationalization of the Vieques movement, and the strengthening of communication via the Internet, anti-military activists closely track each other's struggles and tactics. Activists have long paid attention to state side anti-military struggles and cleanup efforts at Kahlo'olawe, Hawaii and Massachusetts Military Reservation at Cape Cod, with vigilance to any discrepancies in government treatment. Studies of open detonation at the Massachusetts Military Reservation (MMR), among the first to question the safety of open detonation, revealed that open blasts released toxic particles into the air and soil at levels that exceeded guidelines more than $50 \%$ of the time. The EPA ordered the military to use a closed detonation chamber (CDC) to destroy 2,500 rounds of ammunition dug out of burial pits at MMR. ${ }^{17}$ Another study revealed that particulates trapped in the CDC exhaust filter contained hazardous levels of chlorinated and nitroaromatic compounds, lending credence to concerns about toxic byproducts of disposal. ${ }^{18}$ Vieques activists demanded that the Navy utilize CDC on the Vieques range as well, but met with resistance from the Navy, which argued that the size of UXO at MMR was much smaller. Oliveri heralded this as proof of island's second-class political status, the Navy's indifference to residents' health and safety, and the Puerto Rican government's fecklessness:

The U.S. has environmental laws that don't apply here. When the Navy and CHM2Hill started the cleanup back in 2007, they made fires: huge fires with plumes of smoke that carried toxins onto the population. They couldn't do this in the U.S. because it would not be permitted. They wouldn't permit open burning on bases in the United States: here, yes. When CHM2Hill worked in MMR - Camp Edwards - they used the closed chambers there. Camp Edwards, like Vieques, was a firing range since back in the 1940s. There they designed the closed chambers. We asked for those in Vieques. No. In Vieques they did open detonation. All the toxics from the bombs came to us in another form. It continues to impact us. Why don't they follow the law here that they follow there? Because the Puerto Rican Environmental Quality Board doesn't protect us.

more information about the Cease Fire Campaign for safe disposal of waste munitions see: http://cswab.org/resources/cease-fire-campaign/

${ }^{16}$ See for example a website maintained by $7^{\text {th }}$ grade students in Aguadilla, Puerto Rico devoted to Sahara dust http://www.saharadustwarning.com/. The National Weather Service's forecast for Puerto Rico tracks the movement of Sahara particles.

${ }^{17}$ https://cumulis.epa.gov/supercpad/cursites/csitinfo.cfm?id=0100960

${ }^{18}$ https://www.epa.gov/sites/production/files/2015-05/documents/715166.pdf 
Why don't they at least make a claim? People say it's a problem of colonialism. Yes, but it's also the responsibility of employees to do the best they can.

Faced with an impasse between an indignant public and the Navy, civilian members of the RAB pushed for air monitoring stations in a last-bid effort to reassure the public and provide transparency. Fernández explained:

The Navy didn't want to pay for a station. We proposed this as an alternative to blow in place.

The Navy was blasting once a week. My suspicion was that the disposal was not releasing the same amount of energy that was released during the bombing, when the Navy was dropping 200300 bombs per day. We didn't know for sure, so we proposed putting an air monitoring station where people lived. Instead, they put it on base, on the roof of their building at Camp Garcia.

Not surprisingly, the air monitoring stations did not reveal significant contamination. Rather than proving safety, to residents, the stations revealed either ineptitude or the Navy's deliberate efforts to deny their concerns. RAB member Sixto Perez complained: "In Vieques we detect the dust from the Sahara desert, the ashes from the Montserrat volcano, how is it possible that your air monitoring is not detecting anything? We don't accept this data." RAB member Nilda Medina, likewise echoed this sentiment: "The Vieques people are contaminated with cancer, and this data doesn't show anything, then were are our health problems coming from? This data does not satisfy us because it seems illogical that nothing is detected." 19

The RAB pushed for the air monitoring stations to be relocated closer to residential neighborhoods, but at this point, the Navy was discredited. "It took a year, but we got them to move the station near Lujan [closer to town]," explained Fernández.

It was up and running for a year. It would start running eight hours before the blasts and eight hours after to see the change. It didn't record any significant change in that year. People came and stripped the station; they took the batteries and all the metal. It cost the Navy US\$3,000 to replace. At this point, they are pretty much done with the cleanup of the LIA [Live Impact Area].

The RAB in this case did not resolve an intractable conflict involving open detonation, nor did the process envision the board as being more than a passive receptacle of Navy documents. However, it did reveal itself to be an actor, not a mere passive receptacle of the remediation process. This role became more pronounced in the Boca Quebrada, "Smoo-4" site, where RAB mobilized community opposition.

\section{SMOO-4}

Located on the Western side of Vieques, Boca Quebrada is a lagoon that the Navy used as an ammunition dump (Figure 6). According to the Navy, the site was used for thermal destruction and burning of retrograde munitions and other explosive devices from 1969 to 1979. The Navy renamed the site "Solid Waste Munitions Area \#4" and abbreviated it to the acronym "SWMU 4" and calls the site "Smoo-4" in conversation. To add to the confusion, this acronym, along with dozens of others, remain in English in Spanish translations of technical documents, thus making incomprehensible real places, objects and ideas.

Boca Quebrada, aka Smoo-4, emerged as a flash point in the clean up process. It was the first place where the Navy was proposing the final closure of a UXO site, and thus was a very important precedent for how the military would handle UXO remediation. This site revealed the clash in paradigms between the narrow risk assessment approach the Navy adopted, versus the more encompassing cleanup demanded by residents, and the power of the RAB to mobilize citizen opposition.

"The Navy came up with a proposed plan", Daniel Rodríguez explained. The Navy decided that it had adequately addressed the ordnance onsite. "There is always a risk of coming across munitions, so they were going to fence the site. Put in land use controls, that's it. Fish and Wildlife will have their trails and they will

\footnotetext{
${ }^{19}$ Vieques RAB Meeting March 72006.
} 
manage the area. People will traverse it, but that's it. You stay out of the fenced area." Rodríguez paused. "And you know how that went over with the local community."

Research in 2004 (McCaffrey 2006) confirmed that many Vieques residents took deep offense to the transformation of former military lands into a wildlife refuge, and the implication that land need to be protected from residents and their patterns of use, including fishing and crabbing. "Where was Fish and Wildlife when the Navy was bombing?" was a typical comment. "They are going to arrest me for picking up a shell on the land on which I was born?" Over the past decade, activists have organized dozens of marchesonto restricted land to demand expanded access and the return of former military land to civilian use. The idea that the Navy would leave a site without removing all UXO, and resolve any risk by cordoning off land was extremely insulting. "The issue of access resonates with everyone," remarked RAB member Julie Smith. "More than the environmental destruction in the east."

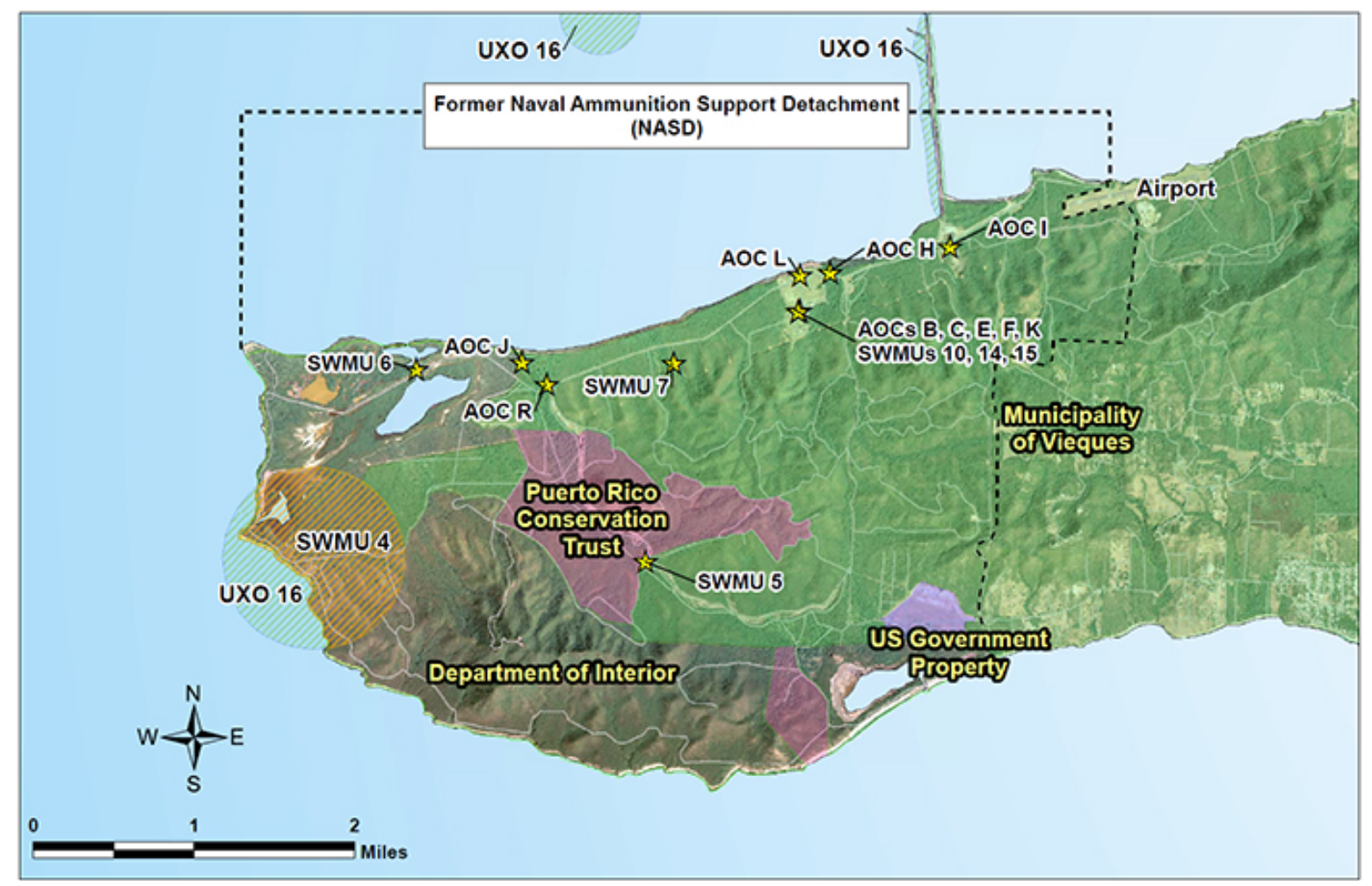

Figure 6: Western Vieques. Map courtesy of Naval Facilities Engineering Command. SWMU=Solid Waste Munitions Area.

Civilian members of the RAB felt that the Navy was ignoring community input and acting unilaterally. Fernández explained: "The frustrating part was that we had come to an agreement on what the solution should be and then we get this presentation from the Navy and what we thought was the answer ended up being the third or fourth option on this list of possible solutions."

When I asked Daniel Hood and Kevin Cloe (lead Remedial Project Managers) the Navy about the Smoo4 controversy, I heard audible sighs. I noted that the RAB felt that its opinion had been overridden. "We installed a fence", explained Hood "The RAB has input-but the group as a whole has to decide on a final solution." He then explained the Navy's rationale in terms of the risk analysis framework with its core assumptions about land use and access influencing pathways of exposure: "That solution should be the most economical and benefit the 
future use of the site. Fish and Wildlife has identified this as a wildlife refuge. ${ }^{20}$ The cleanup is connected to the future land use, and the solution is selected by the team, not just the Navy. It should be the most desirable resolution." Apparently, the engineers did not appreciate Viequenses' antipathy to fences and thought that adding a neighboring park site would obviate any problems. "Two years ago, our plan included a fence—but not just a fence", Hood explained. "This was a 19 acre (7.7 ha) site that included some trails and picnic areas. It was thick and lush and inaccessible. At the $11^{\text {th }}$ hour everyone didn't like the plan."

Fernández explained community antipathy: "They were proposing that the site was cleaned, and that they would put up a barbed wire fence with signs on it declaring the area off limits due to UXO. That was it. Done", he noted:

We said no, there's not even a discussion about this. This is an island; there are hurricanes that change the terrain. What is buried today under forest could be exposed tomorrow. This is an area where people like to go to crab. You have horses, and behind the horses, you have their owners following them. This is not an acceptable solution in terms of human risk. Plus the western area is a big crabbing area. There was a well-attended field trip because a lot of the municipal legislators came. They were showing everybody the crab traps and saying, you can't fence this off! You'll never be able to keep people out of here.

With the Navy poised to submit a proposal declaring the site closed, RAB members mobilized the community. "We put out the proposal to the community", said Fernández. We explained to people that this was a very important precedent for cleaning up UXO." The news sparked public outcry. Activists organized demonstrations on site, and the municipal assembly issued a resolution demanding full cleanup of Boca Quebrada. "The Navy felt that pressure", explained Fernández. Demonstrations, in particular, created headaches. "Another concern for the Navy is liability. They are liable if someone steps on a bomb." The Navy was forced to revise its plan. "We are currently adding on and figuring out a happy resolution", noted Hood. "A solution that makes the public and the landowner happy." Fernández noted that the RAB's participation was crucial in intervening to change the plan. "The interesting thing about the Western plan was that nothing had been implemented. At least we were in on the process as they were contemplating it.... Now they've revisited it and we've gone back to what we thought the solution should be.... I think that the participation of the core RAB members has been essential."

\section{Who supervises the supervisors? The accidental destruction of an ancient forest}

While RAB members counted the Smoo- 4 case as a victory for citizen participation shaping the cleanup process, Navy contractors' inadvertent destruction of a primeval limestone forest offers an unfortunate counterpoint in a complex, top-down regulatory process. This particular case reveals not only the relative powerlessness of the RAB, but also the asymmetry in power relations between the USFWS and the Navy. "The (destruction of the) ECA exemplifies what is wrong with the cleanup process," said Fernández:

This area was declared protected in 1983 and was put off limits to bombing. It was supposed to be left alone. It was a primal dwarf forest. The Navy mostly respected this. When we went out there in 1999, the area was mostly free of ordnance. It came as a big surprise when we learned 2 years after the fact that they destroyed it. In 2008, contractors, looking for UXO, cut down all vegetation. Fish and Wildlife (FW) learned one year later. Imagine (the RAB's) shock to learn about this two years later.

Vieques' landscape is marked by stunning contradictions, the historical outcome of protracted political struggle. The Navy calls its former military lands on the eastern half of the island the Vieques Naval Training

\footnotetext{
20 This assertion is not accurate as the Department of Fish and Wildlife did not decide that former military lands in Vieques would be designated as a refuge: this was the prerogative of Congress. In fact, Fish and Wildlife has found itself the unwitting custodian of many former defense properties, and their ensuing controversies.
} 
Range (VNTR). Within this sector, the military slices different tracts of land to reflect the historic use of this property for maneuvers and bombing: the Eastern Maneuver area (EMA), the Surface Impact Area (SIA) and the Live Impact Area (LIA) (Figure 7). Incongruously, bordered by the bombing range (LIA) and the sea on the easternmost tip of the island lies the "Eastern Conservation area" (ECA), once the site of an extremely rare dry limestone forest.

The creation of the ECA was one consequence of 5 years of grassroots protest in Vieques (1978-1983) that erupted in response to the intensification of maneuvers and bombing of the island. Then Puerto Rican Governor Carlos Romero Barceló settled a lawsuit against the Navy with an accord that is best described as an unenforceable good neighbor agreement. The Navy committed to help local employment and mitigate its environmental destruction. One expression of this was the creation of a series of environmentally protected zones. The Romero accord failed to resolve economic and environmental conflicts that underscored Vieques' conflict with the Navy, but the ECA, incredibly, survived the intensive bombing that surrounded it. Some biologists speculated that the dry limestone forest, also referred to as a "dwarf forest" because of its shortstatured trees, was a primal forest, predating the Spanish conquest. "It was a mature, climatic well-established forest", that hosted unique species of flora and fauna not present in adjacent forests, explained Vieques Refuge Manager Mike Barandiaran. "We (FW) started taking botanists and experts to survey it and they were in awe. This was potentially the best example of dry forest not only in Puerto Rico, but in all of the Caribbean. We were ecstatic." Sometime in 2008, however, Navy contractors razed the dwarf forest as part of the environmental "restoration" process.

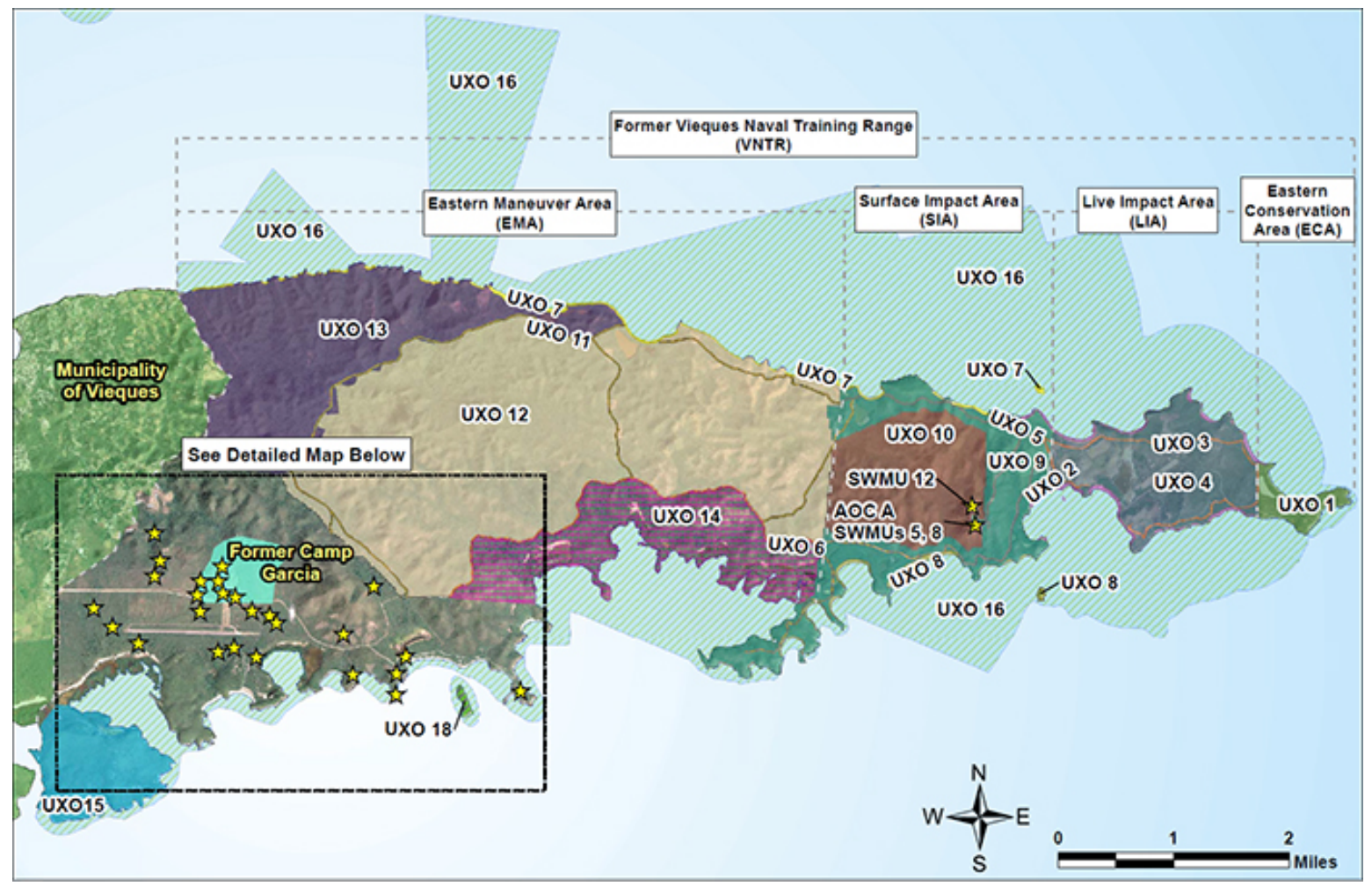

Figure 7: Eastern Vieques. Map courtesy of Naval Facilities Engineering Command.

The destruction of the forest reveals a confluence of shortcomings in the cleanup process. First and foremost it reveals the way that environmental cleanup is narrowly conceived and bureaucratically executed as an ordnance removal operation, an outcome of the EPA's risk analysis framework. It shows the way that bureaucratic protocol is a poor substitute for real communication. It also demonstrates what happens when no 
one supervises the supervisors: although the EPA reviews the Navy's paperwork, the Navy controls site access, and the actual execution of the work plan proceeds without any external, independent oversight. Based on a reductionist understanding of risk that emphasizes ordnance above all other concerns, a contractor hired by the Navy (most of the work has been performed by CH2MHill) develops a work plan; the EPA approves, modifies or rejects it based on its understanding of environmental law; and the cleanup proceeds.

In order to identify ordnance, the Navy typically clear-cuts all existing vegetation in addition to using instruments to detect ordnance. "The Navy is a brute force in clearing vegetation", concluded Barandiaran. The single-minded pursuit of UXO was reflected in the Navy's recollection of the controversy: "This is the way that you remove ordnance. It involves removing vegetation", reported USN Remediation head Kevin Cloe. "The work plan was followed. In 1983, the ECA was set up as a nature preserve. Then when CERCLA came into effect, our mission was to cleanup the range, not maintain a nature preserve. We completed the work as planned in the cleanup work plan." In the case of the ECA, however, clear cutting was probably not necessary. "There was no reason for them to clear cut", said Barandiaran. "This was a limestone shelf: any ordnance would be lying on the surface, clearly visible."

In retrospect, Barandiaran felt that FW should have been more aggressive in monitoring the Navy. "The LIA was such a contaminated area with munitions we said yeah, remove whatever vegetation you have. We gave the Navy too much leeway because they were removing a lot of munitions. The density was so great."21 When the Navy planned to expand its cleanup scope to the ECA, Barandiaran said that FW stressed to them that the area was "a jewel, a treasure, irreplaceable." This conversation, however, was not included in the final work plan, which reflects another limitation of the environmental remediation process: in the absence of real communication between a range of parties, the bureaucracy prevails.

"FW cautioned them not to destroy the forest", Rodríguez explained. "That was done verbally in meetings between FW and the Navy. The EPA was not involved. The community, at previous RAB meetings, warned the Navy that they should be careful about the ECA." None of this input, however, was integrated into a work plan that was probably drawn up off island. "I am seeing more and more over the last few years how much this cleanup is being run by people I don't know, I've never seen, nor heard of. That decisions are made above all of our heads", reflected RAB member Julie Smith who pointed to the ECA fiasco as an "excellent example" of bureaucracy run amok.

Although the Navy and FW agreed to respect the dwarf forest, their agreement was not integrated into the work plan. When the Navy later mentioned this deviation to EPA, the EPA indicated that the military was not conforming to its work plan. "The EPA is not in the habit of telling the responsible parties how to complete their work", explained Barandiaran. The Agency's job is to ensure the Navy's compliance with protocol. In practice, this means "if in doubt, you follow your work plan. So the Navy said all right: cut it all." Rigid adherence to protocol in this case, however, eventuated in the destruction of an ancient forest by the authority of the lead U.S. agency for environmental protection.

"No one in the Navy had the courtesy to pick up the phone and say hey FW, you know what you want us to do? The regulators won't allow us to because it's not in the work plan. That would have given us the heads up", commented Barandiaran. "The whole thing could have been avoided. The EPA could have said—Hey FW - where do you get off telling the Navy to change their work plans without consulting me? The EPA could have called." No one called.

"People were very upset, very upset," reflected Rodríguez:

They felt that the Navy was not listening. FW was very upset because the Navy clear-cut the forest, but FW wasn't doing oversight of the work. They should have been out there, and if they had a concern, they should have told the other agencies so we could have modified the work plan so that we could change the vegetation-clearing plan for that site. None of that was ever done.

${ }^{21}$ To provide some sense of scale, according to the EPA, the Navy located and destroyed 95,000 munitions and 7.1 million pieces of potentially explosive materials in its surface cleaning of 3,600 acres (1,457 ha). https://cumulis.epa.gov/supercpad/cursites/dsp_ssppSiteData1.cfm?id=0204694\#Why [Accessed 12/1/17]. 
The community had a chance to review the work plan—-the community didn't even look at it. So everybody was at fault: nobody took the time during the comment period when the agencies were to review it and the community was to comment. So it happened.

Rodríguez's comments are probably too optimistic in their expectations of participation from both FW and the public. The Navy controls access to the work site. Not even the EPA, which is technically "in charge" of the cleanup, has access to former military lands unless the Navy gives the agency permission to enter. The EPA functions as an information-processing agency, reviewing Navy work plans for compliance with environmental law. The RAB members were certainly not permitted onto the cleanup site, nor FW. Members of the RAB, who are all unpaid lay volunteers, are inundated with an overwhelming mass of highly technical documents that are not produced in Spanish, the primary language of Vieques, and not even really in English, but rather an obscure techno-military variant of the English language, characterized by excessive reliance on incomprehensible acronyms. RAB members are invited to listen to the Navy, but have no authority to revise or reject the work plan.

"I was quitting the RAB. I could not justify working under those conditions", said Fernández. "We are all quitting. But the Navy realized that they needed us. They needed us to justify themselves, so they reached out to us." Fernández described a thaw in the conflict between the RAB members and the Navy:

They were not the ones who bombed us. They are the janitors. One reason we came back was that they wanted to sit down and work with us. Rather than clear cutting, we agreed to new protocol. They would not cut trees with trunks 3 inches or larger. We wanted a map of ecologically sensitive areas - they said they would do this (although they haven't actually done this yet). They agreed to a series of actions that were more costly, but less damaging to the environment. We decided we could sit down and work with them.

Significantly, Fernández noted that the ECA conflict marked the first time that Navy was willing to change its approach.

According to Rodríguez, the Navy integrated a restoration program to accelerate the regrowth of the dwarf forest in its final site plan. The Navy took RAB members out on a site visit, to see what components of reforestation were needed. "To the surprise of those who knew about forestry—nature had taken a good step." "Nature will recover", concluded Barandiaran. "The forest will come back in a thousand years."

\section{Conclusion}

At the time of writing this in early 2017, the Navy has expanded its cleanup operations to the seas surrounding Vieques. Until about ten years ago, the Navy exclusively focused on land-based UXO removal, as it was assumed to present a greater risk, and water cleanup faced technological limitations and a weakness of federal policy. In fact, for many years, disposing spent munitions at sea was considered the safest disposal method and current DoD policy expressly forbids cleanup of sea UXO disposal sites. ${ }^{22}$ Since mid-2000, DoD's munitions response has expanded to address UXO in freshwater, estuarine and marine environments. Some 11,500 underwater acres (4,654 ha) include former ship anchoring points where munitions may have been loaded, areas where munitions may be have inadvertently fired from naval gunfire training or ATG bombing, and artillery ranges extended into the sea.

Recently, the lead Navy official in charge of the remediation plan, Dan Waddill, pointed to the imperfection of the process, and at the same time, revealed the clashing expectations that continue to animate conflict:

\footnotetext{
${ }^{22}$ State of Oregon. Department of Environmental Quality. State Munitions Response Forum Issue Paper. Management of $\underline{\text { U.S. legacy underwater military munitions sites: states' perspectives. }}$
} 
It is true that you can't find everything. It's like- I've lost stuff around my house and I've never found it again. There are tens of thousands of munitions items that we've recovered already. And we've gotten most of them by now. But there are going to be some that we don't find.

What the goal is is that we get enough of it and we have enough controls in place. And a lot of that is just making people aware. If you see a funny looking item don't pick it up. If you know that, if you follow that, you are $99.99 \%$ of the way to being safe. What the goal is is that we make the area safe for people to use as Fish and Wildlife plans for that use. And so we do expect that that goal will be met. You don't have to find every single item in order to reach that. ${ }^{23}$

Waddill's comments, however, reveal the disjuncture between residents and the Navy over the nature and scope of the cleanup process: who decided that the cleanup goal would be to pick up "enough" UXO? Who decided that safety is $99.99 \%$ assured by avoiding funny looking objects? Safety, narrowly constructed as a technical and scientific problem, belies crucial questions that are political in nature: what protections should the public seek? Whose rights should be recognized? What compensation should the government provide? These unresolved political questions animate the contested cleanup process on the island.

Under the Clinton administration (1993-2000), federal agencies were charged with addressing the disproportionate, negative effect of federal policies on minority and low-income communities. The RAB represents one effort to infuse environmental justice concerns into federal policy by creating a public participation vehicle within the environmental remediation process. Ideally, successful public participation should increase both the legitimacy and the effectiveness of policy decisions (Daley and Reames 2015). In Vieques, the RAB has not met its democratizing potential.

As Dietz et al. (2008:7-8) note, successful public engagement recognizes that environmental decisions present complex choices among interests and values and that "choices are political, social, cultural, and economic, at least as much as they are scientific and technical." Despite its significant limitations, within the structure of the RAB, Vieques citizens are able to carve a zone of influence in an otherwise top-down process. In Julie Smith's assessment, "We have won some pretty big small battles in the scope of what is a horribly flawed process."

The RAB is the only entry point residents have into a major environmental remediation process that has direct and significant impact on their health and livelihoods. "Somebody has to be in the room, someone has to be paying attention", noted Smith. "Half the time I don't even understand. This is two-thirds of our island that they're talking about. Initially I stuck with it because I was scared out of my mind, worrying about my health, the health of the people I love."

Jorge Fernández echoed these sentiments and highlighted some of the ways citizen participation has made a difference:

The only reason I am on the RAB is that it is the only place to really learn what is happening, even before things happen, even though you don't have decision power. We have been able to stop some things. The RAB is designed to listen - it is a place where documents are presentedan information exchange, nothing else. We have turned it into something else. We have pushed some decisions. For example: Soil samples. They were doing soil sampling background in the Eastern Maneuver area. We got them to change 30\% of their samples, and include some substances that they had originally had left out. Our input is important to the process.

As the case with Smoo-4 demonstrated, in addition to influencing the process, RAB members have used their position to mobilize public protest. Community members of the RAB took issue with the Navy's unilateral decision to fence off the site which they learned about in a meeting. Although the remediation process itself did

\footnotetext{
${ }^{23}$ Vieques RAB Meeting, February 25, 2015.
} 
not incorporate citizen input, members communicated remediation decisions with activists outside the committee. Vigorous protests on site forced the Navy to revisit its site plan.

Citizen involvement on the RAB has been important not only in sparking public engagement: lobbying from the RAB was crucial to involving the Puerto Rican government in the process. It is common to hear Viequenses lament the lack of interest Puerto Rico's government displays for the wellbeing of citizens in this impoverished, off-shore municipality. Yet in Smith's assessment, the local RAB members have been crucial in engaging the Puerto Rican government to participate in the process:

The Puerto Rican government has always dragged their feet about participating. It's almost a miracle that they are participating in the RAB. It took a lot of effort from the RAB to get them to the table. (Why?) Lack of resources. It wasn't until the government realized that there were resources to support them that they participated. The EQB has some excellent technical advisors who have really helped us understand the process.

Among supporters of Vieques' struggle to demilitarize there remains strong criticism of the cleanup process, mainly because the technocratic process sidesteps larger political questions of accountability for the harm to the civilian population. ${ }^{24}$ Not content to hand their future over to EPA bureaucrats, a wide range of media-savvy activists, such as Nilda Medina, have consistently hammered a no-nonsense message of the Navy's responsibility for cleanup. Medina commented "When the Navy came here they found a beautiful island, with beautiful beaches, with beautiful lagoons with no contamination. They left the area completely contaminated. We want them to do what they have to clean that at the same level that they found it." 25 Grassroots activism, including a direct action campaign (1999-2003) where residents occupied the bombing range for over a year, generated the political will to earn Vieques designation on the National Priority List, a position the former Naval firing range in neighboring Culebra Island never gained in 30 years. Frustration with the technocratic cleanup process, however, has been channeled into criticism over its pace: a position RAB members did not support. In 2014, the office of U.S. Rep. José E. Serrano inserted a provision into the annual defense appropriations bill to force the DoD to fast track the cleanup process. Members of the RAB, however, were worried about this legislation as a stand-alone proposal. "Faster is not necessarily better", commented Fernández:

I really have no problem with the rhythm of the process. The process is slow-you have to have 1,000 people look at each document and give their opinions. The more people who are aware of what's happening, the better. The process allows for more participation and thoughtfulness. To know what's going on, to think about the proposal and give an opinion to the agencies is not necessarily bad. Of course you could always have more money for cleanup, but $40 \%$ of the total budget for munitions cleanup is currently spent in Vieques. Mind you, they have a total 300 billion budget, and only 20 million is being spent on Vieques. I don't think the Navy wants to go slowly - they'd be happy to speed up. The process forces them to take things step by step.

It is precisely this resolute and pragmatic persistence that is informs the current cleanup efforts. However limited the role for citizen input in the process, Smith acknowledges the importance of continued popular pressure in advancing remediation, and the RAB as a tool towards those ends. She commented:

\footnotetext{
${ }^{24}$ On 4/19/2015 the leading Puerto Rican newspaper, El Nuevo Dia, ran an editorial entitled, Environmental debt to the people of Vieques, which called for President Obama to intervene directly in the Vieques cleanup process and lambasted what it described as the ATSDR's criminal pronouncements that failed to connect six decades of live fire practices with high rates of illness on Vieques Island.

${ }^{25}$ W. Rehberg. 2007. Vieques Island activists on bomb range impact: Nilda Medina's witness.
} 
The Navy clean-up to date has exceeded my expectations. I never imagined that we would be at the point we are today. The fact that the agencies are involved, that they are actually cleaning up surface stuff is pretty amazing to me. Because I never thought they would do it. So all of this media pressure, public pressure has been a good thing in the fact that we have a cleanup process going.

\section{References}

Beck, U. 1992. Risk society: towards a new modernity. London: Sage Publications.

Corburn, J. 2005. Street science: community knowledge and environmental health justice. Cambridge, MA: MIT Press.

Daley, D.M. and T.G. Reames. 2015. Public participation and environmental justice. In D.M. Konisky (ed.). Failed promises: evaluating the federal government's response to environmental justice. Cambridge, MA: MIT Press. Pp. 143-171.

Davis, D.L. 2004. When smoke ran like water: tales of environmental deception and the battle against pollution. New York: Basic Books.

Dietz, T., P.C. Stern, and the National Research Council. 2008. Panel on public participation in environmental assessment and decision making, and National Research Council (US) Committee on the human dimensions of global change. Public participation in environmental assessment and decision making. Washington, DC: National Academies Press.

Frickel, S. and K. Moore. 2006. The political sociology of science institutions, networks, and power. Madison: University of Wisconsin Press.

Havlick, D.G. 2018. Bombs away: militarization, conservation and ecological restoration. Chicago: University of Chicago Press.

Holifield, R. 2007. Neoliberalism and environmental justice policy. In N. Heynen, J. McCarthy, S. Prudham and P. Robbins (eds.). Neoliberal environments: false promises and unnatural consequences. London and New York: Routledge Press. Pp. 202-214.

Jasanoff, S. 1986. Risk management and political culture: a comparative study of science in the policy context. New York: Russell Sage Foundation.

Lindsay-Poland, J. 2003. Emperors in the jungle: the hidden history of the U.S. in Panama. Durham and London: Duke University Press.

McCaffrey, K.T. 2002. Military power and popular protest: the U.S. Navy in Vieques, Puerto Rico. New Brunswick, NJ: Rutgers University Press.

McCaffrey, K.T. 2006. The battle for Vieques' future. Centro Journal 18(1): 124-147.

McCaffrey, K.T. 2009. Fish, wildlife and bombs: the struggle to cleanup Vieques. NACLA Report on the Americas. 42(5).

McCaffrey, K.T. 2015. Perpetual war. Anthropology Now 7(2).

Pulido, L., E. Kohl and N.M. Cotton. 2016. State regulation and environmental justice: the need for strategy reassessment. Capitalism Nature Socialism 27(2):12-31.

Shostak, S. 2013. Exposed science: genes, the environment, and the politics of population health. Berkeley: University of California Press.

Sorenson, D.S. 1998. Shutting down the Cold War: the politics of military base closure. New York: St. Marin's Press.

Weinberg, A.M. 1972. Science and trans-science. Minerva (10): 209-222. 


\section{Documentary/Archival Sources}

ATSDR 2001. Focused public health assessment soil pathway evaluation for Isla de Vieques, Puerto Rico. October 25.

Bearden, D. 2005. Vieques and Culebra Islands: an analysis of cleanup status and costs. CRS Report for Congress. The Library of Congress.

Committee on Environmental and Health of the Technical and Professional Support Group for the Sustainable Development of Vieques 2001. Letter to the Agency for Toxic Substances and Disease Registry. Division of Evaluation and Advice on Health. Re: public comment: specific public health assessment, bombing range, Vieques, Puerto Rico evaluation of the route soil. October 23, 2001.

Figueroa, N.R., E. Suárez, T. De La Torre, M. Torres and J. Pérez. 2009. Incidencia y mortalidad de cáncer en Vieques 1990-2004. Registro Central de Cáncer. 25 Nov. 2009.

Naval Facilities Engineering Command: Environmental. Former Atlantic Fleet Weapons Training Area: Vieques. Public meetings and community events. RAB documents. 2001-2016.

State of Oregon. Department of Environmental Quality. State munitions response forum issue paper. Management of U.S. legacy underwater military munitions sites: states' perspectives.

U.S. Environmental Protection Agency. 1996. Final report of the Federal Facilities Environmental Restoration Dialogue Committee. Consensus principles and recommendations for improving federal facilities cleanup.

U.S. Environmental Protection Agency. 2016. Military munitions/unexploded ordnance.

U.S. Environmental Protection Agency. 2017. Superfund site information. Site information for Atlantic Fleet Weapons Training Area.

Zavala-Segarra, D. Incidencia de cáncer en Vieques, 1960-1964. Registro de Central de Cáncer, División de Vigilancia Epidemiológica y Estadísticas, Departamento de Salud de Puerto Rico, November 1999. 